\title{
When conservation precedes development: a case study of the opening up of the Socotra archipelago, Yemen
}

\author{
Paul Scholte, A b dulraqueb Al-Okaishi and Ahmed Saed Suleyman
}

\begin{abstract}
The Socotra archipelago, Yemen, in the north-west Indian Ocean, has outstanding endemic biodiversity, and was listed as a World Heritage Site in 2008. Although inhabited for 6 millennia Socotra only began to open up to the outside world in 1990. With conservation interventions starting prior to major developments, and building on centuries-old low-intensity resource management, Socotra has been in a unique position to practice pre-emptive conservation. In 1997 modern conservation started with biodiversity and socio-economic surveys, with inputs from communities and decision makers, which fed into the Conservation Zoning Plan. Approved in 2000, this has been the archipelago's principal conservation planning and management tool. Regulations and bans on fishing practices, the collection of coral stones and export of biological materials have all been relatively well complied with by local communities and authorities. Inappropriate road construction, however, driven by non-islanders, has demonstrated the limits of the Conservation Zoning Plan, highlighting significant institutional challenges in planning and coordination. The capacity of the Socotra-based conservation institution has increased dramatically over the last decade. Its personnel are generally respected, largely because their roles include assisting local communities with development initiatives, underlining the importance of integrating conservation and development at the onset of conservation. Although the integrity of the landscape will inevitably decline, especially along the northern coastline, Socotri conservationists, backed by international support, are in a unique position to shape the archipelago's future.
\end{abstract}

Keywords Conservation Zoning Plan, endemism, ICDP, pre-emptive conservation, protected areas, Socotra, World Heritage Site, Yemen

\section{Introduction}

Situated in the north-west Indian Ocean the Socotra $\checkmark$ archipelago is characterized by high levels of endemism,

Paul Scholte* (Corresponding author), Abdulraqueb Al-OKaishi and Ahmed Saed Suleyman Socotra Conservation and Development Programme, Socotra, Yemen. E-mail pault.scholte@gmail.com

Ahmed SAed Suleyman Environmental Protection Authority, Socotra, Yemen

${ }^{\star}$ Current address: Kitabi College of Conservation and Environmental Management, s.c. Nieuwe Teertuinen 12 C, 1013 LV Amsterdam, The Netherlands

Received 22 February 2010. Revision requested 16 July 2010.

Accepted 7 October 2010. with $37 \%$ of its plant species endemic, comparable to oceanic archipelagos such as the Galapagos and Canary Islands (Miller \& Morris, 2004). This richness can be attributed to the islands' diverse topography and precipitation patterns (Scholte \& De Geest, 2010) and their continental origin, separated from what is now Dhofar, Oman, 18 million years ago (Van Damme, 2009). The islands' mountains may have remained above sea level since Precambrian times (Cheung \& DeVantier, 2006). Several of Socotra's endemic plants, such as the dragonblood Dracaena cinnabari (Plate 1), frankincense (Boswellia spp.) and aloes (Aloe spp.) have historically played a significant role in the global economy (Miller \& Morris, 2004). The archipelago's endemic flora and fauna and diverse marine environment was acknowledged by its designation as a UNESCO World Heritage Site in 2008.

Recent genetic research suggests that Socotra was settled from the Arabian mainland as early as 4,00o BC (Cerny et al., 2009). Archaeologists believe that incense collection, the so-called gold of the East, drew people to the islands. The first proofs of human presence on Socotra are in the form of inscriptions found in a cave dating from $258 \mathrm{AD}$ (Robin \& Gorea, 2002). By the 4th century AD, when the demand for incense had declined, the population turned to animal husbandry, fishing and local trade for survival, remaining in relative isolation (Naumkin, 1993). No evidence has been found of mass extinctions of flora or fauna induced by the arrival of humans, as on other oceanic islands (Steadman, 1995), although records from early texts suggest the possibility of the loss of land tortoises and other reptiles (Van Damme, 2009).

In contrast to Socotra's long-term habitation is its isolation. The strong south-west monsoon makes the islands inaccessible for half of the year. Although ruled by communist South Yemen from 1968 onwards, owing to its strategic importance, access to the archipelago remained limited. Only with the unification of North and South Yemen in 1990 did Socotra begin to open up to the outside world.

The UN-led Socotra Biodiversity Programme, succeeded by the Socotra Conservation and Development Programme (SCDP) and, recently, the Socotra Governance and Biodiversity Project, commenced in 1997, prior to the initiation of major infrastructural developments (an all-year round airport, tarmac roads and a seaport). This offered a unique chance for pre-emptive conservation (Spring et al., 2007). There has, however, been concern over the lack of impact of 


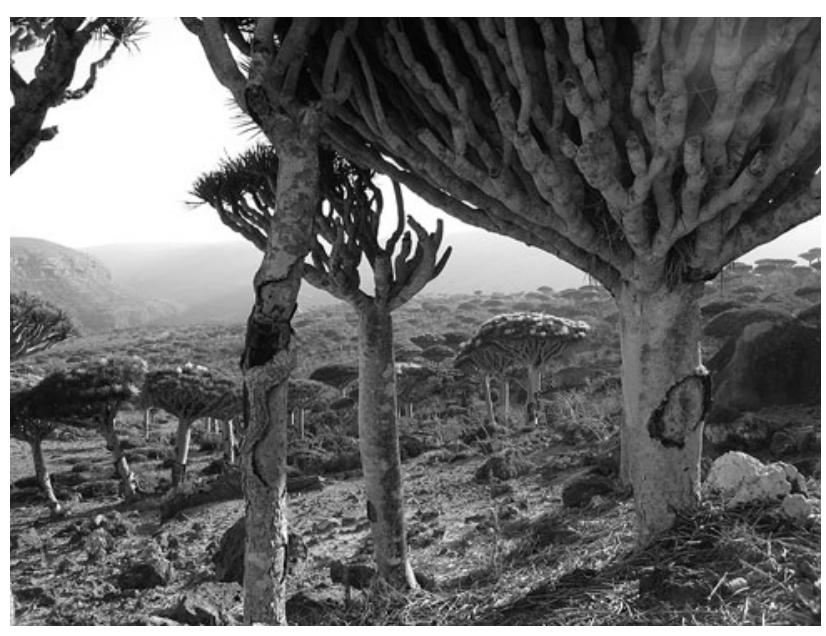

Plate 1 The dragonblood tree Dracaena cinnabari. Exploitation scars (see tree to right) are testament to the historical economic importance of the species (Firmihin, March 2007, photograph by Paul Scholte).

integrated conservation and development projects (ICDPs) such as the SCDP because of overambitious goals and negative impacts of development on conservation (Sunderland et al., 2008).

The Socotri have developed an intrinsic knowledge of their environment, exploiting resources at low intensities (Morris, 2002). It is tempting to attribute dramatic biodiversity losses, as seen on the Pacific Ocean islands, for example (Steadman, 1995), to the late implementation of conservation efforts, undertaken when development was already well advanced. However, the early designation of $97 \%$ of the land surface of the Galapagos archipelago as a protected area did not prevent it being listed as a World Heritage Site in danger (Watkins \& Cruz, 2007). We hypothesize that the environment on Socotra with its long-resident human population, is better managed than on islands with predominantly immigrant populations.

This article is a case study of conservation in the Socotra archipelago, drawing on a variety of information sources. We present Socotra's ecological and social context, and describe the conservation interventions on the archipelago. This allows us to examine (1) the rationale of an integrated conservation-development approach, (2) the advantages of having a long-term resident population, and (3) the value of pre-emptive conservation.

\section{Socotra}

The Socotra archipelago (Fig. 1) includes Socotra and the smaller islands of Samha, Darsa and Abd al Kuri. At $3,695 \mathrm{~km}^{2}$ Socotra comprises the igneous Hagghier Mountains (maximum altitude 1,526 m; Fig. 2), limestone plateaus and alluvial coastal plains. From October to April Socotra is under the influence of the wet north-east monsoon

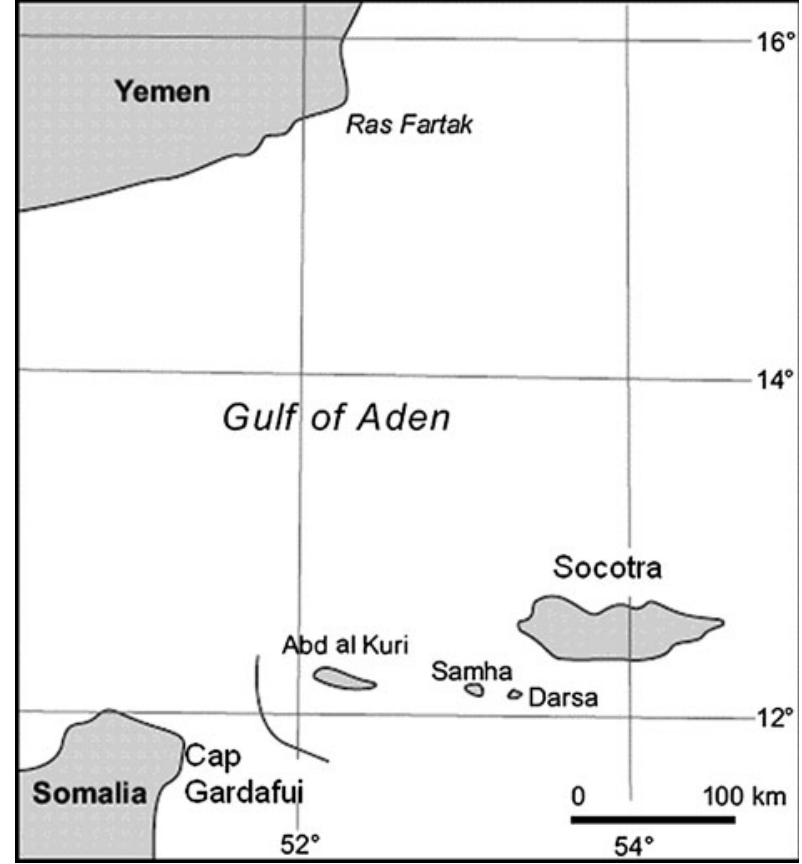

Fig. 1 Location of the Socotra archipelago (Socotra and the smaller islands of Samha, Darsa and Abd al Kuri) in the northwest Indian Ocean.

and from June to September the hot and dry south-west monsoon causes high waves along the southern coasts and gale-force winds along the northern coasts. Mean total annual rainfall is $216 \mathrm{~mm}$ although precipitation in the mountains, including fog, may reach $800 \mathrm{~mm}$, allowing the growth of patches of stunted forest (Scholte \& De Geest, 2010).

For centuries Socotra's main economic activity was animal husbandry, predominantly goats, but also sheep on the limestone plateaus and dwarf cattle in the mountains. Transhumance has been the principal strategy to exploit the rangelands, whose quality and quantity are influenced by the islands' topographical and climatic diversity. Socotra's pastoral history is reflected in its land tenure system, characterized by overlapping grazing claims. With increasingly permanent land uses, such as agriculture and tourism, exclusive land rights are being claimed and are often a source of conflict.

Socotra's institutions, mostly transposed from the mainland, have undergone profound changes over the last century. Socotra used to be part of the Mahra Sultanate, in which the Sultan ruled, through his representative and a retinue of tax farmers, by fear and superstition (Elie, 2008). The socialist government (1968-1990) integrated the cave-dwelling Bedouin in the mountains, agropastoralists in the interior plains and artisanal fishermen in the coastal areas into a civil society run by a party-controlled hierarchical system of committees. New institutions provided education, food relief and palliative health services. With 




FIG. 2 Conservation Zoning Plan and tarmac road construction programme (source: EPA-SCDP conservation department).

unification of Yemen in 1990 freedom was obtained to practise religion, trade and travel. The village committees of the previous regime continued functioning on an informal level, alongside the new administration (Elie, 2008). Since 2000 the Socotra archipelago has comprised two districts, which depend on the mainland Hadramout governorate: Hadibu in the centre and east with c. 32,000 inhabitants, and Qalansiya in the west with c. 12,000, and the islands of Abdul al Kuri (500 people), Samha (250 people) and Darsa (uninhabited). Most ministries (Fisheries, Agriculture, Health, Education) are represented, albeit with a low capacity. Although Yemen has engaged in administrative decentralization, most strategic decisions continue to be made centrally.

Conservation on the archipelago should be interpreted against a background of accelerating pressures. Tourist numbers have doubled every 18 months since 2003 (Fig. 3). Artisanal fishing of tuna and kingfish, involving most of the coastal population, has more than doubled over the last decade (Fig. 4). Pressure on sea cucumbers, lobsters and sharks seems to have increased, although there is a lack of precise figures. Agriculture, which used to be limited to date palm plantations and small home gardens, is expanding, using imported fertilizers, seeds and pesticides and draining sparse freshwater resources. The number of goats is assumed to be increasing and their omnipresence is thought by many to be responsible for the lack of regeneration of the islands' trees, as well as degradation of the land (Mies, 2001). Socotra is also experiencing rapid urbanization, with the capital Hadibu having grown, largely unplanned, from 500 to 10,000 inhabitants since 1970 . The city's infrastructure is

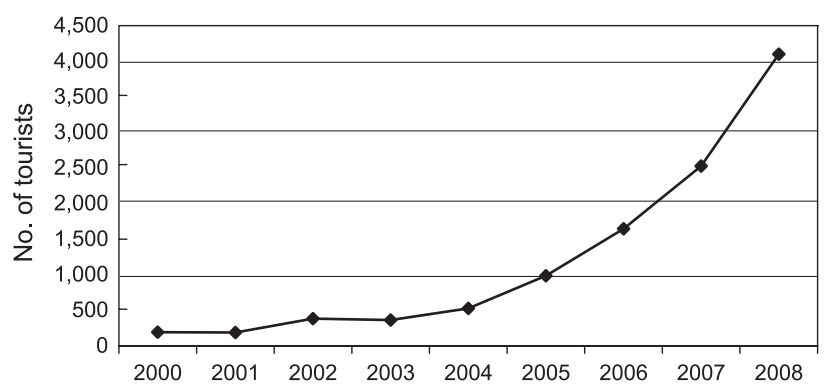

Fig. 3 Development of foreign tourism on Socotra, 2000-2008. Numbers includes $\pm 15 \%$ of non-touristic foreign visitors (source: Socotra police, tourism department). 


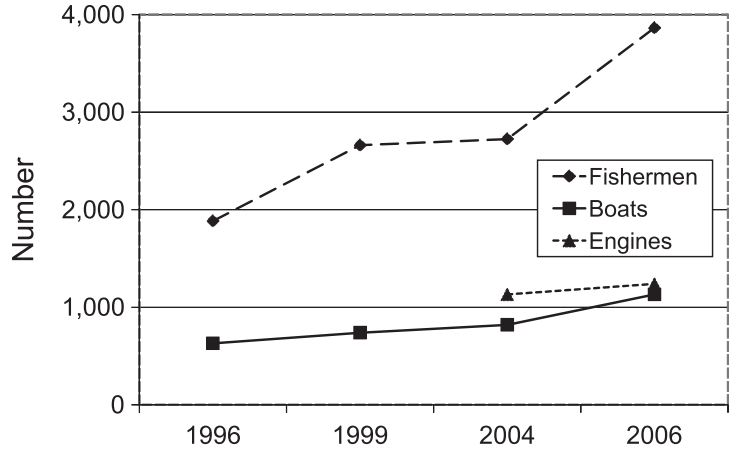

FIG. 4 Increase in fisheries efforts, 1996-2006 (source: EPA-SCDP marine programme).

poor, with wastewater treatment, for example, still in the planning stage.

\section{Methods}

Employed by the SCDP, we were able to draw on unique unpublished information and insight. A drawback of this could be the potential for bias but we balance our account by referring to published sources and unpublished reports and communications with external experts, including the IUCN World Heritage Site evaluation (D. Sheppard, pers. comm. 2008) and project evaluations (M. Infield et al., pers. comm. 2000; Infield \& Al Deen, 2003; Gawler \& Mansour, 2009). In addition, we organized a session at the 2007 Synoptic Biogeography of Socotra Archipelago Workshop (Senckenberg Institute and Sana'a University, in Sana'a, Yemen) to gain insight from recent biodiversity studies and their consequences for the Conservation Zoning Plan, and we draw upon this session.

The SCDP has been at the forefront of conservation on Socotra, making it difficult to separate a discussion on conservation interventions from programme-related matters. The SCDP has not had a monitoring and evaluation system (M. Gawler \& H. Mansour, pers. comm. 2009) but has put in place a network of largely qualitative monitoring sites for coral reefs (Cheung \& DeVantier, 2006) and vegetation. It is, however, beyond the scope of this case study to quantify the impact of development activities and so we limit ourselves to qualitative descriptions.

A wide variety of development is taking place on the Socotra archipelago. We focus on those that threaten the integrity of its outstanding parts, designated as World Heritage Site property, rather than on the dramatic environmental changes in the general-use zones, especially the towns of Hadibu and Qalansiya, and the resource-use zones that include $92 \%$ of the marine area (Fig. 2).

\section{Conservation and development}

\section{Biodiversity inventories}

Starting with the 1888 Balfour expedition, Socotra's flora and fauna have regularly attracted scientists (Wranik, 2003). The
1956 Oxford expedition produced a vegetation map of the island (Gwynne, 1968) that was included in White's (1983) Vegetation Map of Africa. Socotra has subsequently been considered part of Africa in conservation assessments (e.g. Burgess et al., 2004) and field guides (e.g. Van Perlo, 1996).

During the Cold War the archipelago was closed to Western scientists but attracted scientists from the Eastern Bloc (Wranik, 2003). With the start of the SCDP there was an increase in inventories of the terrestrial and marine environments and land use (Mies, 2001; Morris, 2002; Wranik, 2003; Krupp, 2004; Miller \& Morris, 2004). These studies confirmed the relatively intact vegetation and the low levels of exploitation, suggesting no immediate threat to the islands' biodiversity. Socotra was placed in the lowest threat category of the WWF Ecoregion Classification Scheme, unlike some other oceanic islands (Burgess et al., 2004). Subsequent assessments (Rodrigues et al., 2004) ranked Socotra as a low conservation priority. Nevertheless, several risks had been identified at an early stage: a lack of regeneration of dragonblood and frankincense trees because of overgrazing and climate change (Miller \& Morris, 2004) and the potential for overfishing (Cheung \& DeVantier, 2006).

\section{Translation of research into plans, policies and decrees}

The Conservation Zoning Plan was conceived based on the opinions of experts involved in the 1997-1999 biodiversity inventories and a programme of community outreach. Local communities, sheikhs and authorities were consulted, and there were discussions of the concept of conservation and of the Zoning Plan and assurances were given that people would not lose their land. The majority, especially the older generation, supported the process because they considered it a way to conserve traditional land use at a time when uncertainty, particularly against the socialist backdrop of state-owned land, prevailed. The resulting Plan did, with some exceptions, meet the expectations of stakeholders. The exceptions, from a conservation perspective, were most notably the Ma'alah plateau and Firmihin (Fig. 2), with its dragonblood forest, which did not receive exclusive protection status because the local communities feared relinquishing its present land use.

In 2000, after intensive negotiations at higher political levels, the Conservation Zoning Plan was approved by presidential decree, the first of its kind in the Arabian region, and became the legal base for conservation on the archipelago. The terrestrial Plan, covering 3,695 $\mathrm{km}^{2}$, was designed following the Biosphere Reserve Concept (Batisse, 1982), dividing the archipelago into nature sanctuaries (core zones, 2.5\%), national parks that include areas of special botanic interest, such as the Ma'alah plateau and Firmihin (core zones, $72.6 \%$ ), as well as resource-use (buffer zones, $23.5 \%$ ) and general-use zones (transition zones, 1.4\%; Fig. 2). These protected area categories use the IUCN criteria 
(Dudley, 2008) but in a modified form, and this holds true especially for the national parks, home to most of Socotra's rural population and considered as communally-protected land. The marine Plan, covering $17,819 \mathrm{~km}^{2}$, is predominantly composed of a 12-mile $(22.2 \mathrm{~km})$ zone of resource-use reserves (92\%), with the remaining area comprising national parks (core zone, $7 \%$ ) and nature sanctuaries (core zone, $1 \%$ ). The Plan is a spatial planning instrument, targeting uncontrolled developments in sensitive areas, generally by governmental and private interventions, and provides a framework to continue extensive traditional land use.

During 2001-2006 management plans were formulated and subsequently implemented based on agreements between local communities and the Environmental Protection Authority (EPA), in the main involving nature sanctuaries and surrounding national parks. The areas covered by the plans were selected based on tribal divisions, with as few overlapping claims as possible. Plans comprised micro-zoning based on community needs, protected area status and management practicalities. In subsequent years EPA staff recruited community members to monitor the plans.

The European Union mission in Yemen commissioned a master plan for the development of Socotra. The consultants, who interacted with the SCDP-EPA team in 2000, produced investment plans for the main economic sectors (fisheries, livestock, tourism), services (health, waste and sanitation, roads) and local governance. Although approved by the Ministry of Planning the master plan has, however, never been implemented.

\section{Community development activities}

Communities agreed on the designation of nature sanctuaries based on the understanding they would be assisted in tapping into funds stemming from ecotourism, as an alternative to restricted use (Table 1). Communities were assisted in the construction and subsequent management of tourist campsites in the protected areas of Homhil, Dihamri, and subsequently Skand and Amak (Fig. 2). The latter, with a spectacular beach, was selected to prevent development by private investors and to promote community use. The Dihamri community (Fig. 2) partnered with a German dive company and received over 1,500 tourists in 2008.

\section{Conservation interventions}

An external evaluation of the SCDP, involving 30 in-depth interviews with SCDP-EPA stakeholders, was conducted in late 2008 (M. Gawler \& H. Mansour, pers. comm. 2009). The results indicated unanimous agreement on the programme's impact at the policy level and on its environmental relevance and capacity-building impact. Opinions were more divided, however, about the relevance to
Socotra's development of the activities undertaken and on the sustainability of the mechanisms put in place (Fig. 5). Below we review the conservation interventions undertaken and whether they have contributed to the development of institutional mechanisms, and other issues of sustainability.

\section{International recognition of the importance} of Socotra's biodiversity

Formal recognition of the importance of Socotra's biodiversity began with the identification of 22 Important Bird Areas (Evans, 1994). A decade later, with improved knowledge of the endemic plant species of Socotra and Somalia, the Horn of Africa was recognized as one of 34 global biodiversity hotspots (Thulin, 2004). Socotra was also included in WWF's Global 200 Ecoregions (Burgess et al., 2004), albeit misleadingly categorized as desert. In 2003 the archipelago was inscribed as a reserve under UNESCO's Man and the Biosphere Programme, followed in 2008 by its listing as a World Heritage Site. Alongside these formal recognitions there has been increasing media coverage of Socotra, both nationally and internationally, including pieces in The New York Times in 2007 and 2008, and almost weekly coverage in the Yemeni national press.

\section{Bans and regulations: the Conservation Zoning Plan}

The World Heritage evaluation (D. Sheppard, pers. comm. 2008) concluded: 'Overall the Zoning Plan has been applied successfully, although not without challenges, including inappropriate road development'. The Conservation Zoning Plan and the bans and regulations met little resistance (Table 1). This may be due to the high level of consultation but also because, through the Plan, communities were able to secure ownership of the land.

In contrast to local communities, compliance from governmental services has been more difficult to achieve. While the non-compliance from the Agriculture and Fisheries services could be solved relatively easily, as it was rooted in poor communication (Table 1), in other areas the conflict has been more difficult to overcome. This is particularly the case for the road system, on which Yemen has spent c. USD 70 million (Minister of Water and Environment, pers. comm. 2008), the highest per capita road expenditure in the country. Since the start of tarmac road construction in 2000 there have been tensions between the EPA and the Ministry of Roads regarding road design and placement (Cheung \& DeVantier, 2006; Scholte, 2007). Road construction in nature sanctuaries is banned, yet in various instances roads have been planned to cross them. The most notable case was when the northern ring road connecting Hadibu with Qalansiya (Fig. 2) did not follow the old valley track but was instead cut into seawards cliffs, threatening to cross Qalansiya Lagoon, a nature sanctuary with rich bird life and 
TABLE 1 Compliance and resistance to conservation bans and regulations in Socotra.

\begin{tabular}{|c|c|c|c|c|c|}
\hline Topic & $\begin{array}{l}\text { Ban/ } \\
\text { regulation }\end{array}$ & Year & Compliance $^{1}$ & Resistance $^{2}$ & Notes \\
\hline Qat Catha edulis cultivation ${ }^{3}$ & Ban & $2000^{4}$ & ++ & - & $\begin{array}{l}\text { Although feasible there is strong resistance against } \\
\text { qat cultivation amongst local communities }\end{array}$ \\
\hline Export of biological materials & Regulation & $2000^{4}$ & $+/-$ & $+/-$ & $\begin{array}{l}\text { Regulated upon authorization but several of } \\
\text { Socotra's endemic plant species are offered for } \\
\text { sale abroad. }\end{array}$ \\
\hline Import of biological materials & Regulation & $2000^{4}$ & $+/-$ & $+/-$ & $\begin{array}{l}\text { Regulated upon authorization. Import of livestock \& } \\
\text { some live materials has been banned but } \\
\text { a probably increasing number of less conspicuous } \\
\text { agricultural species enter unnoticed. }\end{array}$ \\
\hline $\begin{array}{l}\text { Turtle collection } \\
\text { (eggs, live animals) }\end{array}$ & Ban & $2000^{4}$ & $+/-$ & ++ & $\begin{array}{l}\text { Despite presence of an active community-survey } \\
\text { programme }\end{array}$ \\
\hline $\begin{array}{l}\text { Road construction in } \\
\text { nature sanctuaries }\end{array}$ & Ban & $2000^{4}$ & $+/-$ & + & $\begin{array}{l}\text { Frequently stiff resistance from non-Socotri } \\
\text { owned construction company, occasionally from } \\
\text { local communities (see text \& Fig. 2) }\end{array}$ \\
\hline Trawling & Ban & $2000^{4}$ & - & - & Little control on foreign-owned trawlers. \\
\hline Fishing in nature sanctuaries & Ban & $2000^{4}$ & $+/-$ & $+/-$ & \\
\hline $\begin{array}{l}\text { Building restrictions in nature } \\
\text { sanctuaries \& on the coast line }\end{array}$ & Ban & $2000^{4}$ & $+/-$ & $+/-$ & \\
\hline Lobster fishing & Regulation & 2002 & $+/-$ & + & $\begin{array}{l}\text { Ban on taking juveniles \& females with eggs, } \\
\text { facilitated by the introduction of live traps. }\end{array}$ \\
\hline Coral stone & Ban & 2006 & + & $+/-$ & $\begin{array}{l}\text { Coral stones no longer harvested but disputes } \\
\text { remain on previously collected stones, still } \\
\text { stocked at beaches. }\end{array}$ \\
\hline Sea cucumber & Ban & 2006 & + & - & $\begin{array}{l}\text { Activity of non-Socotris; upon lifting of ban, } \\
\text { activity started again in } 2010\end{array}$ \\
\hline
\end{tabular}

$1_{++,}$full; +, general; +/-, partial; -, limited

${ }^{2}$ Amongst Socotra residents: ++, frequent; +, present; +/-, slight; - none

${ }^{3}$ Qat Catha edulis is a mild drug consumed daily by many, especially mainland Yemenis and, to the dismay of many Socotris, the consumption of qat flown in from the mainland is spreading. In early 2009 the local council of Hadibu installed a ban on the transport of qat to the island but this is contested by qat sellers who note that the island is part of Yemen and not ruled by independent laws.

${ }^{4}$ Formally installed by the 2000 presidential decree, the Conservation Zoning Plan has gradually been rendered operational in subsequent years.

outstanding scenery. After international pressure, and intervention from the President, the road was diverted, abandoning $10 \mathrm{~km}$ of tarmac road already constructed.

The construction of roads in national parks and coastal areas, although not banned, has frequently brought conflict between the EPA and the Ministry of Roads; for example, there was disagreement concerning the width of roads, which at $8 \mathrm{~m}$ surpassed the size of the road connecting Yemen's capital Sana'a with its harbour Hudeidah (Scholte, 2007). Conservation opposition to road construction grew in 2007 when the Ministry of Roads, through the only road construction company, presented plans for a southern ring road (Fig. 2). The route threatened to cross cliffs that are home to many endemic plant species and seabird colonies, and met with strong international resistance (Scholte, 2007). Local councils and donors also voiced their concern, suggesting only a limited number of people would benefit from these multimillion dollar investments (see, for example, the lack of villages around its trajectory; Fig. 2). Later in 2007 an agreement was signed between the newly appointed Ministers of Environment and Roads stipulating that every new road had to be approved by the EPA. This has improved collaboration between representatives of the two ministries but their opinions on road-building remain largely in opposition to each other.

We attribute these conflicts to the fact that responsibility for the implementation of the Conservation Zoning Plan has remained exclusively with the EPA. Although signed by the President, other ministries and authorities feel only limited responsibility for the Plan. Furthermore, although there is a strong international lobby for the conservation of the archipelago there is only limited national pressure for its conservation and the wise use of scarce financial resources for its development.

\section{Management plans for protected areas}

In 2007 an internal management plan review suggested that progress had been made in conserving the environment, with increasing benefits for local people through community-run campsites and related ecotourism. Considered even more important was the experience gained by 


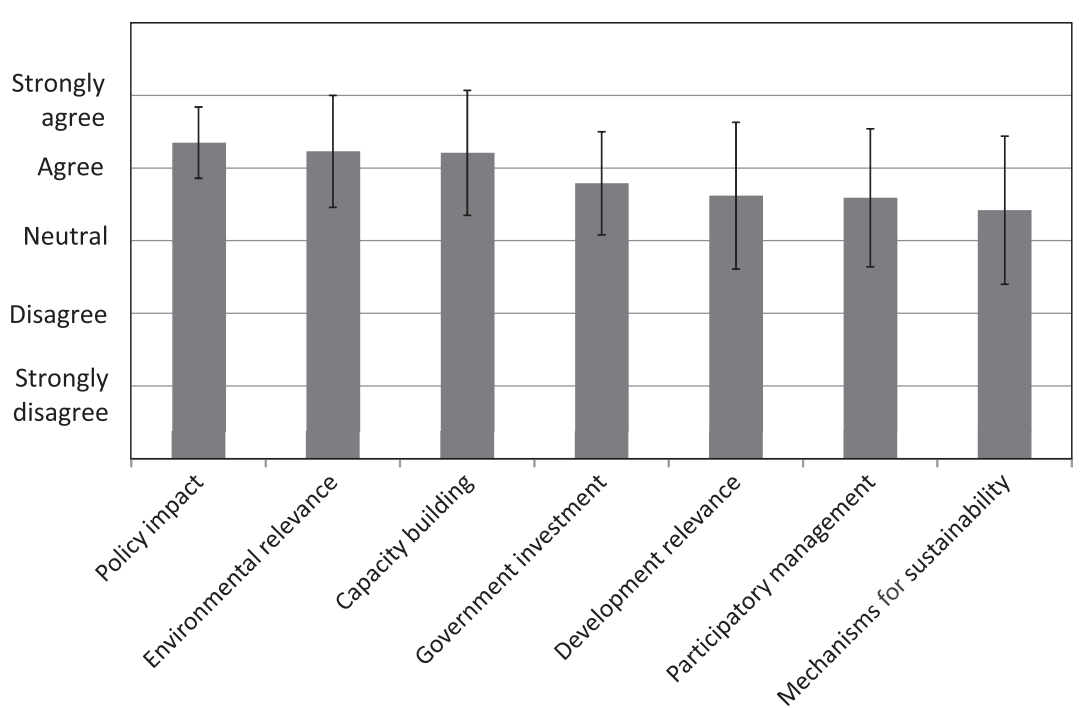

Fig. 5 Achievements of the Socotra Conservation and Development Programme (SCDP), as expressed by the responses of stakeholders in interviews held during the final evaluation (from the external evaluation of the SCDP; M. Gawler \& H. Mansour, pers. comm. 2009) to the question 'The Project has been successful with regard to its ....... Interviewees $(\mathrm{n}=30)$ included direct beneficiaries (30\%), local authorities (20\%), the SCDP-EPA team (17\%), the UNDP (10\%), the National Government (10\%), donors (7\%) and others (7\%). Values are means \pm SD. communities and programme staff. The review proposed that revised plans should counter the impact of rising numbers of tourists on the environment by improving waste management and introducing the use of solar energy. Another point highlighted was the illegal fisheries in Dihamri Nature Sanctuary (Fig. 2), revealed by a drop in fish diversity in surveys conducted in 2007. The EPA subsequently strengthened its supervision.

\section{Developing insights on Socotra's ecology, management and institutions}

Institutional gaps leading to autonomous development

In 2000 the need was expressed for an island-wide authority (M. Infield et al., pers. comm. 2000) to fill the gap between the



Plate 2 Goats are the main source of economic production in rural areas and have helped shape Socotra's current landscape (West Hagghier, May 2008, photograph by Paul Scholte).
EPA, with its mandate for regulation, and district authorities, with their focus on service delivery. This gap was most notable in the planning and coordination of developments imposed from the Capital. Following conditions for the World Heritage Site listing, the creation of an authority was ordered by cabinet decree in February 2008 and raised by the President during a visit to Socotra in March 2009. Several cases of noncompliance with bans and regulations (Table 1), especially those related to road construction, can be attributed to this institutional gap. This is also the case for the lack of appropriation of the EU master plan by any of the technical ministries. Consequently, development on Socotra has remained largely autonomous and driven from outside.

The need for ecological understanding and conservation instruments

Long-term surveys have increased knowledge of biodiversity hotspots such as the Ma'lah limestone plateau (Fig. 2), second only to the Hagghier Mountains in terms of its plant diversity (A. Miller, pers. comm. 2008). Nevertheless, the Conservation Zoning Plan did not foresee a strict protection status with respect to a ban on road construction for these biodiversity hotspots. However, with their designation as World Heritage Site property, large-scale developments in these areas have become controversial.

It has previously been assumed that the erratic rainfall and high goat-grazing pressure would prevent the spread of exotic plant species on the Socotra archipelago, as evidenced by their low abundance compared to other oceanic islands (Watkins \& Cruz, 2007; Sax \& Gaines, 2008). However, some of the cryptogenic species, such as Argemone mexicana, observed as long ago as 1888 (A. Miller, pers. comm. 2007), have shown recent dramatic increases. Highly invasive species (e.g. Prosopis juliflora and Opuntia spp.) have now also colonized Socotra from the mainland 
(A. Senan, pers. comm. 2008). With the start of international flights and increased arrivals of ships there are already signs of an acceleration of the arrival of invasive flora, with the possibility that a $1: 1$ ratio between naturalized and native plant species could be reached, as already manifested on other oceanic islands (Sax \& Gaines, 2008).

Goats are considered to be one of the most notorious alien species on many oceanic islands, driving plants to extinction and leading to habitat destruction (Campbell \& Donlan, 2005). Yet, goats, which were probably introduced by the first settlers on Socotra $>2$,00o years ago, are the main source of economic production in its interior (Naumkin, 1993; Plate 2). Socotra has been shaped by humans and their livestock, and yet no plant species are immediately threatened because of the pressure of goat grazing (Miller \& Morris, 2004). Scholte \& De Geest (2010) argued that it is not absolute goat-grazing pressure that has an impact on biodiversity but the reduction of spatial and temporal grazing dynamics. New management techniques (water provision, veterinary care, supplementary fodder and transport), and abandonment of the custom of slaughtering new-born male goats to maximize milk production to produce ghee, have greatly increased the survival of goats. Formerly, low grazing pressure in post-drought periods allowed the regeneration of plants but this is no longer the case. New practices will have to be developed to mimic the old patterns.

\section{Forthcoming challenges and opportunities}

In the mid 2000 s poverty on Socotra was at the national average (Government of Yemen et al., 2007), which was an improvement on its previously presumed status as the poorest and most disadvantaged part of the country. Whereas in the late 1990s to the early 2000 s the annual budget of development agencies working on Socotra in health care, education, nutrition and agriculture was $<$ USD 100,000, this increased to USD 1 million in 2008. There has also been increasing investment interest in the islands by visitors from the United Arab Emirates, many with family ties on Socotra.

A decade ago all senior SCDP staff, the conservation managers on the island, were expatriates, with some mainland Yemenis at middle-management level. This has changed with the establishment of the EPA branch on Socotra, which is led by c. 20 Socotri technical staff and is recognized as one of the biggest achievements of the SCDP (Fig. 5). However, there is still some concern about their limited number given the variety of tasks (D. Sheppard, pers. comm. 2008). Tourism on the island is increasingly driven by local associations and private initiatives, with all rural tourism facilities run by local communities. This capacity may also help with the planning of protected areas elsewhere in the country, as already shown when SCDPEPA personnel supported the management planning of the mainland protected areas of Hawf, Bura'a and Aden.
Conservation has been driven by the EPA and the Ministry of Water and Environment, in collaboration with development partners (the UN Development Programme and bilateral cooperation) and scientific institutions from Germany, the UK, Italy and the Czech Republic. With the exception of BirdLife International, conservation NGOs and the private sector have, so far, been largely absent, although horticultural companies did express initial interest to conclude benefit-sharing agreements with the Government of Yemen to commercialize Socotra's endemic plant species.

Funding for development has increased several-fold, whereas conservation funds have declined over the last decade. A concern is the continuing dependency on shortterm outside funding (D. Sheppard, pers. comm. 2008), although there has been an increase in government funding through the recruitment of EPA personnel. There is more potential for funds to be tapped; the island-wide administration, currently being created, has received the mandate to raise entrance fees to the archipelago.

\section{Discussion}

Millennia of relative isolation, a low human population density, rich traditional knowledge and lack of economic development have resulted in a relatively intact biodiversity and resource base on Socotra. The opening up of the archipelago, which began after the initiation of conservation interventions, led, however, to acceleration in land-use change that started decades earlier (Elie, 2008), and the rapidly developing threats were underestimated by global and continent-wide conservation assessments (Burgess et al., 2004; Rodriguez et al., 2004). Based on our experience with the SCDP and this review of the available information, we draw three principal lessons.

\section{Rationale of an integrated conservation-development approach}

In assessing the effectiveness of conservation interventions on Socotra we are methodologically limited by lack of 'with versus without' opportunities for comparison, as almost all low-intensity areas were designated protected areas. Nevertheless, several changes were conservation achievements: the increased international recognition, and compliance with environmental regulations (Table 1), and the experience gained by members of the EPA team and local communities. The annual cost of conserving Socotra (including development seed-money), which amounts to USD $274 \mathrm{~km}^{-2}$ of terrestrial World Heritage property, is low compared with the cost of conservation on the Galapagos (USD 2,549 km $\mathrm{km}^{-2}$; Gonzales et al., 2008). The higher level of pressure from tourism on the Galapagos and its more extensive marine area could explain some of the difference.

Although ICDPs have been widely criticized (Sunderland et al., 2008), the experience on Socotra shows that at the onset 
of conservation an integrated approach has a distinct advantage. It allowed the establishment of long-term conservation mechanisms (the Conservation Zoning Plan and World Heritage Site listing) as well as bans and regulations reacting to newly emerged threats (Table 1). The integrated approach has played a decisive role: the attention paid to development has enhanced goodwill amongst local communities and empowered conservation. This approach, already contested (Elie, 2008), cannot continue working with increasingly development-oriented partners. Instead, it has been suggested that the approach should evolve into an island-wide authority, charged with planning, supervision and coordination. Now being created, this will embody an institutionalization of the integrated conservation and development approach.

\section{The advantages of having a long-term resident population}

The habitation of Socotra stretches back for millennia, resulting in intrinsic local knowledge and the practice of low-intensity resource management. Socotra is an ancient island from both a social and geological perspective. Its nickname, Galapagos of the Indian Ocean (Sohlman, 2004), is misleading given the Galapagos' relative geological youth and predominantly immigrant population (Grenier, 2000).

Compliance with environmental regulations by Socotra's predominantly rural population (Table 1) has resulted in the success of local conservation interventions. However, the present high levels of immigration may jeopardize this, as shown by the struggle over the construction of the excessive road system in which benefits only go to a small group from the mainland. On the Galapagos it was the immigrant fishermen community that triggered the conservation crisis in the mid 1990s (Grenier, 2000). Despite Socotra's advantage in possessing a long-term resident population, its governmental institutions are generally biased in favour of immigrants with connections to central institutions, highlighting the need for a counterbalance by local institutions. This is an area where experience from other regions can provide support, and merits further guidance, including research.

\section{The value of pre-emptive conservation}

The ultimate question is whether pre-emptive conservation has placed Socotra in a better position to tackle future conservation challenges. Despite the decline of sea cucumbers, lobsters and sharks, the seas around Socotra are still relatively pristine. One of the principal reasons for this is the 6 months during which the sea is closed for artisanal fishing but this is not necessarily a barrier to larger vessels in the future. Despite road construction, urban expansion and other developments, especially in coastal areas, visitors to Socotra's interior can still see stands of endemic dragonblood trees, desert rose Adenium obesum and cucumber trees Dendrosicyos socotrana. Substantial new knowledge has been gained on the composition and evolution of Socotra's cultural landscape (Miller \& Morris, 2004; Attorre et al., 2007), and the challenge is to translate this knowledge into management guidelines.

With limited human and financial resources, the expansion of the islands' population and increasing development needs, realism about conservation targets needs to prevail. Inevitably a planned new seaport and forthcoming agricultural and other development projects will further affect the integrity of Socotra's landscapes. Nevertheless, by having committed and qualified Socotri conservation staff, backed by international partners and armed with its World Heritage status (Van Damme, 2009), Socotra is in a better position to influence future changes than if conservation interventions had begun after the onset of development.

\section{Acknowledgements}

The SCDP, under the auspices of which we have been working, was implemented by the Ministry of Water and Environment and the UN Development Programme with Global Environment Facility and bilateral co-funding. Opinions expressed in this article are those of the authors only. We would like to thank our colleagues Nadem Taleb, Salem Dahaq, Malek Abdulaziz, Fuad Naseeb, Mohammed Kaed and Ahmed Issa, and Essam Sulaihi, Kader Bensada and Fuad Ali for fruitful collaboration. Ali al Salami prepared the maps. Abdul Rahman Al-Eryani, Richard Porter, Tony Miller, Eduardo Zandri, Flavia Pansieri, David Sheppard, Diana Quiroz, Omar Al-Saghier and Fabio Attorre have all been sources of many stimulating discussions. We thank Catherine Cheung, Lyndon DeVantier, Mark Infield, Stephany Kersten, Colin Smith, Kay Van Damme and two anonymous reviewers for their critical comments.

\section{References}

Attorre, F., Francesconi, F., Taleb, N., Scholte, P., Saed, A., Alfo, M. \& Bruno, F. (2007) Will dragonblood survive the next period of climate change? Current and future potential distribution of Dracaena cinnabari (Socotra, Yemen). Biological Conservation, $138,430-439$.

B Atisse, M. (1982) The biosphere reserve. Environmental Conservation, 9, 101-111.

Burgess, N., D'Amico Hales, J., Underwood, E., Dinerstein, E., Olson, D., ItouA, I. et al. (2004) Terrestrial Ecoregions of Africa and Madagascar. A Conservation Assessment. Island Press, Washington, DC, USA.

Campbell, K. \& Donlan, C.J. (2005) Feral goat eradications on Islands. Conservation Biology, 19, 1362-1374.

Cerny, V., Pereira, L., Kujanova, M., Vaoikova, A., Hajek, M., Morris, M. \& Mulligan, C. (2009) Out of Arabia-the settlement of Island Soqotra as revealed by mitochondrial and $\mathrm{Y}$ chromosome genetic diversity. American Journal of Physical Anthropology, 138, 439-447.

Cheung, C. \& DeVAntier, L. (2006) Socotra, A Natural History of the Islands and their People. Odyssey Books \& Guides, Hong Kong. 
Dudley, N. (ed.) (2008) Guidelines for Applying Protected Area Management Categories. IUCN, Gland, Switzerland.

Elie, S.D. (2008) The waning of Soqotra's pastoral community. Human Organization, 67, 335-345.

Evans, M.I. (1994) Important Bird Areas in the Middle East. BirdLife International, Cambridge, UK.

Government of Yemen, World Bank \& UNDP (United Nations Development Programme) (2007) Yemen Poverty Assessment. Http://web.worldbank.org/WBSITE/EXTERNAL/COUNTRIES/ MENAEXT/YEMENEXTN/o, content MDK:21579495 pagePK:1497618 piPK:217854 theSitePK: 310165,00.html [accessed 11 May 2009].

Grenier, C. (2000) Conservation contre nature. Les iles Galápagos. Institut de recherche pour le développement, Paris, France.

Gwynne, M.D. (1968) Socotra. Acta Phytogeographica Suecica, 54, $79-85$.

Krupp, F. (ed.) (2004) Socotra. Fauna of Arabia, 20, 1-548.

Mies, B. (2001) Flora und Vegetationsokologie der Insel Soqotra. Essener Okologische Schriften 15. Westarp Wissenschaften, Essen, Germany.

Miller, A.G. \& Morris, M. (2004) Ethnoflora of the Socotra Archipelago. Royal Botanic Garden, Edinburgh, UK.

Morris, M. (2002) Manual of Traditional Land Use Practices in the Soqotra Archipelago. GEF YEM/96/632 Report. The Royal Botanic Garden, Edinburgh, UK.

Na um in, V.V. (1993) Island of the Phoenix. An Ethnographic Study of the People of Socotra. Ithaca Press, Reading, UK.

Robin, C. \& Gorea, M. (2002) Les vestiges antiques de la grotte de Hoq (Suqutra, Yémen). In Academie des Inscriptions et Belles-Lettres, Comptes rendus des séances de l'année 2002, avril-juin, 409-445.

Rodrigues, A.S.L., Aкçakaya, H.R., Andelman, S.J., BaKarr, M.I., Boitani, L., Brooks, T.M. et al. (2004) Global gap analysis: priority regions for expanding the global protected-area network. Bioscience, 54, 1092-1100.

SAX, D.F. \& Gaines, S.D. (2008) Species invasions and extinction: the future of native biodiversity on islands. Proceedings of the National Academy of Sciences of the United States of America, 105, $11490-11497$.

Scholte, P. (2007) Roads in Yemen's Protected Areas. Presentation to EU ambassadors Sana'a. Http://www.johnfarrar.plus.com/ Roads\%20on\%20Socotra\%20and\%20Yemen.pdf [accessed $8 \mathrm{Au}$ gust 2009].

Scholte, P. \& De Geest, P. (2010) The climate of Socotra Island (Yemen): a first-time assessment of the timing of the monsoon wind reversal and its influence on precipitation patterns and vegetation. Journal of Arid Environments, 74, 1507-1515.

Sohlman, E. (2004) A bid to save the 'Galapagos of the Indian Ocean'. Science, 303, 1753.

Spring, D.A., Cacho, O., Mac Nally, R. \& Sabbadin, R. (2007) Pre-emptive conservation versus 'fire-fighting': a decision theoretic approach. Biological Conservation, 136, 531-540.

Steadman, D.W. (1995) Prehistoric extinctions of Pacific island birds: biodiversity meets zooarchaeology. Science, 267, 1123-1131.

Sunderland, T.C.H., Ehringhaus, C., \& Campbell, B.M. (2008) Conservation and development in tropical forest landscapes: a time to face the trade-offs? Environmental Conservation, 34, 276-279.
Thulin, M. (2004) Horn of Africa. In Hotspots Revisited (eds R.A. Mittermeier, P. Robles-Gil, M. Hoffmann, J.D. Pilgrim, T.M. Brooks, C.G. Mittermeier et al.), pp. 277-283. Cemex, Mexico City, Mexico.

VAn Damme, K. (2009) Socotra archipelago. In Encyclopedia of Islands (eds R.G. Gillespie \& D.A. Clague), pp. 846-851. University of California Press, Berkeley, USA.

Van Perlo, B. (1996) Birds of Eastern Africa. Harper Collins, London, UK.

Watkins, G. \& Cruz, F. (2007) Galapagos at Risk: A Socioeconomic Analysis of the Situation in the Archipelago. Charles Darwin Foundation, Galapagos, Ecuador.

White, F. (1983) The Vegetation of Africa (at 1:5,00o,ooo scale). Natural Resources Research Series, 20. UNESCO, Paris, France.

Wranik, W. (2003) Fauna of the Socotra Archipelago-Field Guide. Rostock University, Rostock, Germany.

\section{Biographical sketches}

Paul Scholte was team leader of the SCDP from 2005 to 2008. Previously, he worked as a range ecologist in Yemen and Chad, taught at Garoua Wildlife College and coordinated the Waza-Logone floodplain rehabilitation and park management planning in Cameroon. He is now Principal of Kitabi Wildlife College, Rwanda. Abdulraqueb Al-Okaishi is an animal husbandry and tropical forestry specialist and an expert on Socotra's zoology. Employed by the SCDP since the late 1990 os he has been leading the community protected area programme on the archipelago. AHMED SAED SUlEYMAN is the deputy director of EPA-Socotra and heads the SCDP-EPA conservation team. He has been the driving force in monitoring and, where necessary, opposing, road construction on the island. $\mathrm{He}$ is a keen birdwatcher and guide and is much concerned with the socio-economic development of his native Socotra.

\section{Postscript: Socotra and the Arab Spring}

Yemen is, according to media, on the brink of civil war. Recent alarming articles in Nature Middle East (22 March and 25 May 2011) reported the departure of foreign researchers and tourists from Socotra and suggested that the conservation infrastructure is collapsing. However, in calls to my colleagues on Socotra in early June I learnt that, although they are very worried about the political situation, life for the Socotri continues as usual: fishermen were travelling to the Hadramout for the monsoon period and early monsoon rains have greened the island. Moreover, my colleagues are able to work normally. Although governmental and international links are temporarily weakened I am optimistic that, as Socotri conservationists remain connected to their communities and have a strong conservation ethos, the gains made by conservation programmes will not be lost.

Paul Scholte, 29 June 2011 